\title{
Spectral Analysis of Eight Polymers in SIMS by MO Calculation. Prediction of Cleavage of Polymers and Structural Formula of the Positive-Ion Fragment
}

\author{
Kazunaka Endo, ${ }^{\dagger}$ Takahiro Hoshi, ${ }^{*}$ Naoya KobaYASHI, \\ Hidetoshi Miura, and Masahiro KUdo** \\ Tsukuba Research Laboratory, Mitsubishi Paper Mills, Ltd., \\ 46 Wadai, Tsukuba, Ibaraki 300-42, Japan \\ * Analytical Laboratory, Ulvac-phi Inc., 2500 Hagisono, \\ Chigasaki, Kanagawa 253, Japan \\ ** Department of Applied Physics, Faculty of Engineering, Seikei University, \\ Kichijoji, Musashino, Tokyo 180, Japan
}

(Received November 8, 1996)

\begin{abstract}
Spectra of eight polymers $\left[\left(\mathrm{CH}_{2}-\mathrm{CHR}\right)_{n}\left(R=\mathrm{H}, \mathrm{OH}, \mathrm{F}, \mathrm{Cl}, \mathrm{OCH}_{3}\right.\right.$, and $\left.\left.\mathrm{CONH}_{2}\right),\left(\mathrm{CF}_{2}-\mathrm{CF}_{2}\right)_{n}\right]$ and $\left(\mathrm{CH}_{2}-\mathrm{CHCN}\right)_{n}$ in time-of-flight (TOF)- and static(S)-secondary ion mass spectrometry (SIMS), respectively, were analyzed by semiempirical and ab initio molecular orbital (MO) calculations. We predicted where the cleavage of the polymers occurs on sputtering, due to two-center bond energies of the model pentamers by a semiempirical MO calculations using AM1 program; a) the cleavage can occur in any bonds (polyethylene, poly(vinyl methyl ether), polyacrylonitrile), b)the cleavage of the main chain occurs in any bonds, after side chain groups cleaved first (poly(vinyl chloride, poly(acrylamide)), c) the main chain carbons with the side chain group cleave at any bonds of the main chain (poly(vinyl fluoride, poly(tetrafluoroethylene), poly(vinyl alcohol)). We also determined the possible structural formulas of the secondary positive-ion fragments in the range of $0-100 \mathrm{amu}$ by ab initio MO calculations using the HONDO7 program.

KEY WORDS Seconday Ion Mass Spectroscopy (SIMS) / Ab Initio and Semiempirical Molecular Orbitals

/ Positive Secondary Ions / Bond-Order / Polymer /
\end{abstract}

Time-of-flight secondary ion mass spectrometry(TOF SIMS) has become a powerful tool for studying polymer surfaces. TOF-SIMS provides a direct method of determining the mass resolved image on the order of micron along cross section of different polymers and other material/polymer blends. On the other hand, information $^{1-5}$ of basic chemical analysis obtained from TOF SIMS includes monomer molecular weight, fragmentation patterns, molecular weight distribution of oligomers and spectra characteristic of a specific polymer family. However, there is no study about spectral analysis of polymers in SIMS by molecular orbital (MO) calculations, since the emission process of secondary ions, atoms or molecules on sputtering is very complicated. In a part of the previous work, ${ }^{6}$ we demonstrated that the cleavage of polymer-bond for polypropylene, polystylene and poly(methyl methacrylate) could be predicted, as follows; bond-orders of the model 5- or 3-mers from semiempirical MO calculations.

This is a comprehensive study on prediction of the cleavage of bonds for polmers(polyethylene (PE), poly(vinyl alcohol) (PVA), polyacrylonitrile (PAN), poly(vinyl fluoride) (PVF), poly(vinyl chloride) (PVC), poly(vinyl methyl ehter) (PVME), poly(acrylamide) (PAM), and poly(tetrafluoroethylene) (PTFE)) on sputtering in SIMS due to bond-orders (or two-center bond energies) of the model pentamers from semiempirical MO calculations using AM1 program. ${ }^{7}$ The cleavage sites of bonds were estimated from the size of two-center bond energies. We were thus able to classify the cleavage of the polymer bonds into three cases. We also determined the possible structural formulas of the secondary positive-ions by $a b$ initio $\mathrm{MO}$ calculations using HONDO7 program. ${ }^{8}$

\section{MO CALCULATIONS}

The electronic structures of model pentamers $[\mathrm{H}-$ $\left(\mathrm{CH}_{2}-\mathrm{CHR}\right)_{5}-\mathrm{H}\left(R=\mathrm{H}, \mathrm{OH}, \mathrm{CN}, \mathrm{F}, \mathrm{Cl}, \mathrm{OCH}_{3}\right.$, and $\left.\left.\mathrm{CONH}_{2}\right), \mathrm{F}-\left(\mathrm{CF}_{2}-\mathrm{CF}_{2}\right)_{5}-\mathrm{F}\right]$ were based on using a semiempirical AM1 program (version 6.0). Bond-orders and two-center bond energies ${ }^{9}$ of the model pentamers of (PE, PVA, PAN, PVF, PVC, PVME, PAM, PTFE) polymers were obtained from optimized results by the energy gradient method.

The electronic structures of the fragment positive-ions for eight polymers were obtained by ab initio calculations using the HONDO7 program. For the geometry of the fragment positive ions, we used optimized cartesian coordinates from the AM1 program. In the $a b$ initio calculations, we used a restricted Hartree-Fock(RHF)/4$31 \mathrm{G}$ basis set for $\mathrm{H}, \mathrm{C}, \mathrm{N}, \mathrm{O}, \mathrm{F}$, and $\mathrm{Cl}$ atoms.

\section{EXPERIMENTAL}

\section{Materials}

We used commercially-available polyethylene (PE) (Aldrich Chemical Co., Inc.; high density), poly(vinyl alcohol) (PVA) (Wako Pure Chemical Industries, Ltd.; $M_{w}$ 22000), poly(vinyl fluoride) (PVF) (Scientific Polymer Products, Inc.), poly(vinyl chloride) (PVC) (Aldrich

\footnotetext{
† To whom correspondence should be addressed.

Present address: Department of Chemistry, Faculty of Science, Kanazawa University, Kakuma-machi, Kanazawa, Ishikawa 920-11, Japan.
} 
Chemical Co., Inc.; $M_{w}$ 83500), poly(vinyl methyl ether) (PVME) (Scientific Polymer Products, Inc.), poly(acrylamide) (PAM) (Aldrich Chemical Co., Inc.), and poly(tetrafluoroethylene) (PTFE) (Scientific Polymer Products, Inc.).

Samples were prepared by cast-coating the polymer solution on an aluminium plate, while methyl ethyl ketone and water were used for PVC and (PVA, PVME, PAM) polymers, respectively. For PE, PVF, and PTFE, we used the film or the pressed disc. The film was found to be a few tens of micrometers thick. For PAN, we cite results using static SIMS measurements. ${ }^{10}$

\section{TOF SIMS Measurements}

We used a PHI TOF SIMS TFS-2000 spectrometer with a primary $\mathrm{Ga}^{+}$ion beam $\left(12 \mathrm{keV} \mathrm{Ga}^{+}\right.$, pulse with $13 \mathrm{~ns}$, repetition rate $10 \mathrm{kHz}$, primary ion current of $700-800 \mathrm{pA}$ measured as a continuous beam). The generated secondary ions were accelerated to $3 \mathrm{keV}$. The intensity changes of the given ion species during the irradiation of the primary ion beam (denoted as dose profiles) were evaluated through an ion dosage up to $2.5 \times 10^{12}$ ions $\mathrm{cm}^{-2}$. A new charge compensation system, based on a low-energy electron source $(10 \mathrm{eV})$ and a pulsed extraction field of the mass analyzer, provides a self-adjusting surface potential for all kinds of insulators in positive and negative SIMS modes. In the present work, we used the positive and negative modes except for the PAN polymer.

\section{RESULTS AND DISCUSSION}

Cleavage and Secondary Ion Mass Spectra of Polymers

Let us consider a simplified process related to the emission of a fragment ion from solid polymer surface. When a polymer sample is bombarded by ions of a few ten $\mathrm{keV}$ kinetic energy, an impact cascade and excited area are created around the point of primary particle impact through energy and momentum transfer from the bombarding particles to solid polymer. Fragment ions are then formed by dissociation of sputtered neutral molecular species. Surface fragment ions are thus emitted, if a sufficient amount of energy is transfered. The results of the dissociation of PP, PS, and PMMA polymers, as shown in previous work, ${ }^{6}$ seem to correspond to the thermal decomposition in Mass Spectrometry.

In the previous work, we obtained positive-ion fragment spectra of three polymers in the mass range of $0-100 \mathrm{amu}$. The fragment spectra seemed quite simple. We predicted where the cleavage of the polymers occurs on sputtering, although the emission process of secondary ions, atoms or molecules on sputtering is very complicated. We estimated the cleavage sites of polymerbonds for eight polymers from the size of the bond-orders and two-center bond energies of the model pentamers by the semiempirical AM1 program (in Figure 1).

In Figure 1, the two-center bond energies of PE, PVME and PAN models in any atom-atom bonds without considering the $\mathrm{C}-\mathrm{H}$ bonds are similar: 0.99-1.00 $(14.0-14.2 \mathrm{eV}), 0.96-0.99(13.7-14.0 \mathrm{eV})$, and 0.96 $0.98(13.8-14.0 \mathrm{eV})$, respectively. We can, thus, see that the cleavage of the polymer-bonds occurs at any bonds.

For PVC and PAM, the two-center bond energies of $\mathrm{C}-\mathrm{Cl}$ and $\mathrm{C}-\mathrm{CO}\left(\mathrm{NH}_{2}\right)$ showed 10.8 and $13.1 \mathrm{eV}$ less than 14.3 and $14.0 \mathrm{eV}$ for main chain $\mathrm{C}-\mathrm{C}$ bonds, respectively. Thus, cleavage of the main chain of the polymers yield, after side chain groups $\left(\mathrm{C}-\mathrm{Cl}\right.$ and $\mathrm{C}-\mathrm{CO}\left(\mathrm{NH}_{2}\right)$ cleaved first.

In Figure 1, the two-center bond energies of the main chain $\mathrm{C}-\mathrm{C}$ bonds of PTFE were evaluated as $12.0 \mathrm{eV}$, thus being much less than $17.2 \mathrm{eV}$ of $\mathrm{C}-\mathrm{F}$ bonds. For PVA, the main chain bonds were estimated as $14.0 \mathrm{eV}$ slightly less than $14.3 \mathrm{eV}$ of $\mathrm{C}-\mathrm{OH}$ bonds. In the case of PVF model, the two-center bond energies of the main
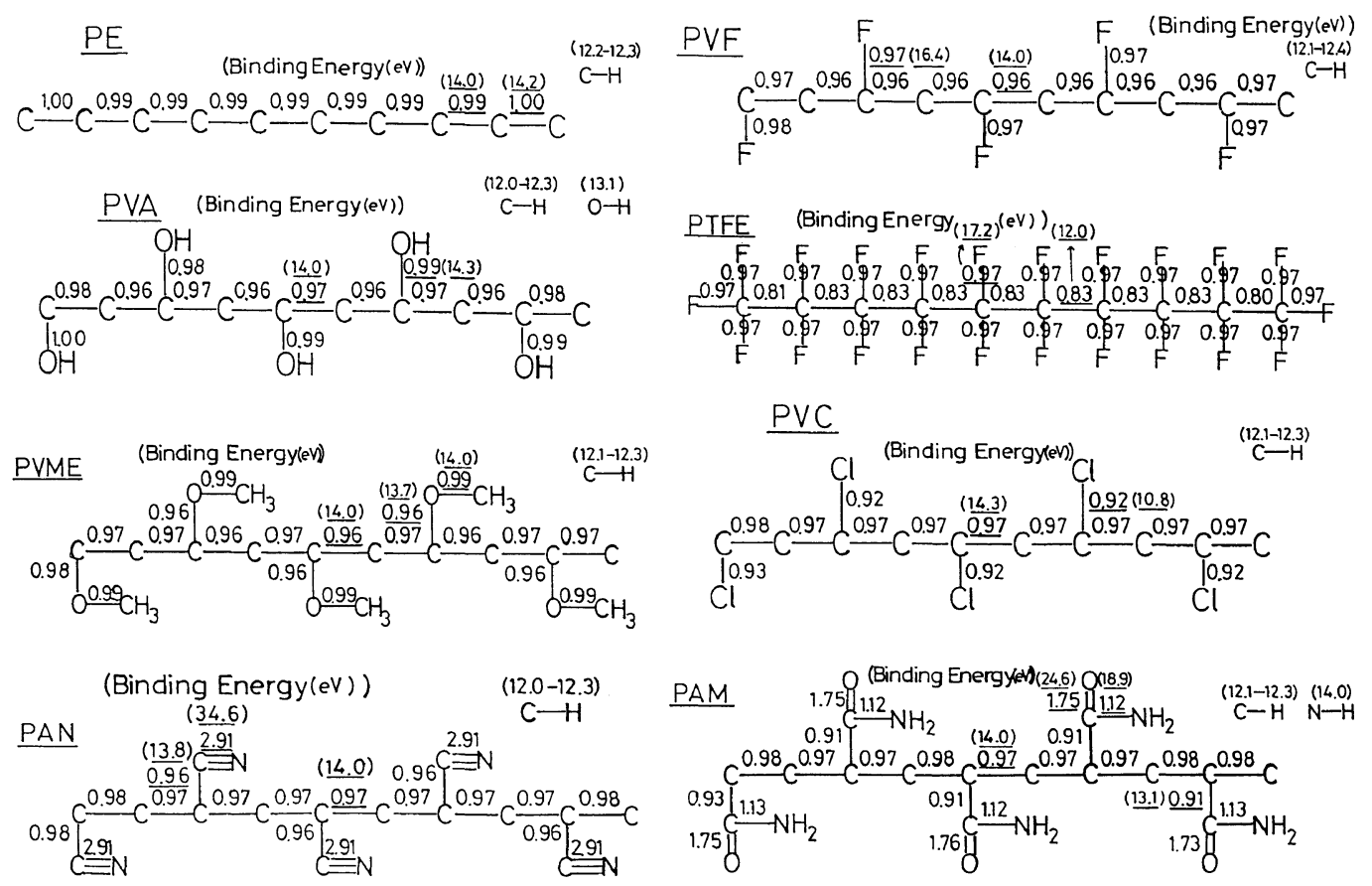

Figure 1. Bond-orders and two-center bond energies (in eV) of the pentamers of eight polymers by the semiempirical MO calculations using the AMl program. 
(a)
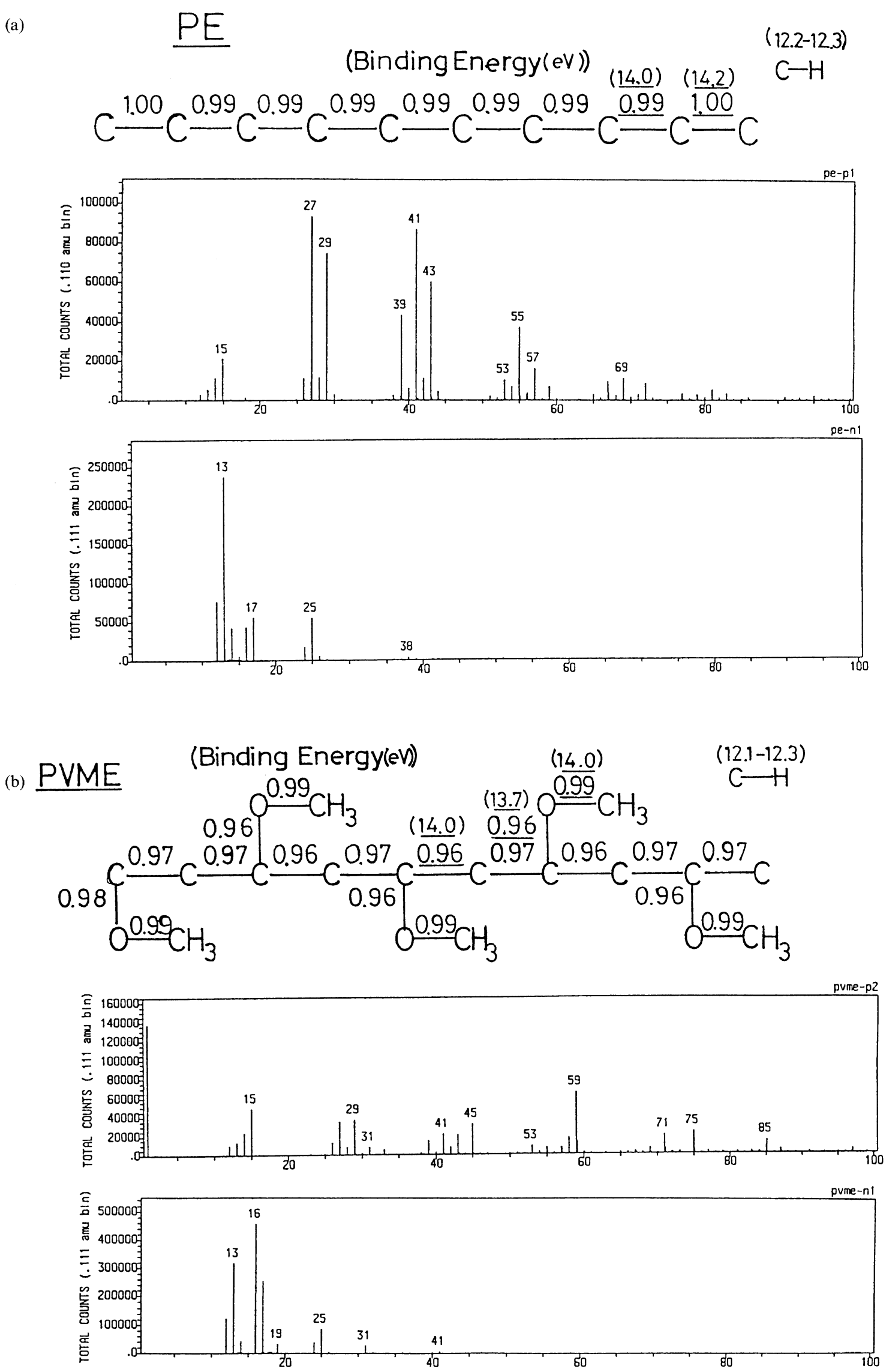

Figure 2. (a) Bond-orders and bond energies (in eV) of the pentamer of PE by semiempirical MO calculation using AM1 program (upper); positive and negative ions TOF-SIMS spectra of PE in the range of $0-100 \mathrm{amu}$. (b) Bond-orders and bond energies (in eV) of the pentamer of PVME by semiempirical MO calculation using AM1 program (upper); positive and negative ions TOF-SIMS spectra of PVME in the range of $0-100 \mathrm{amu}$. 

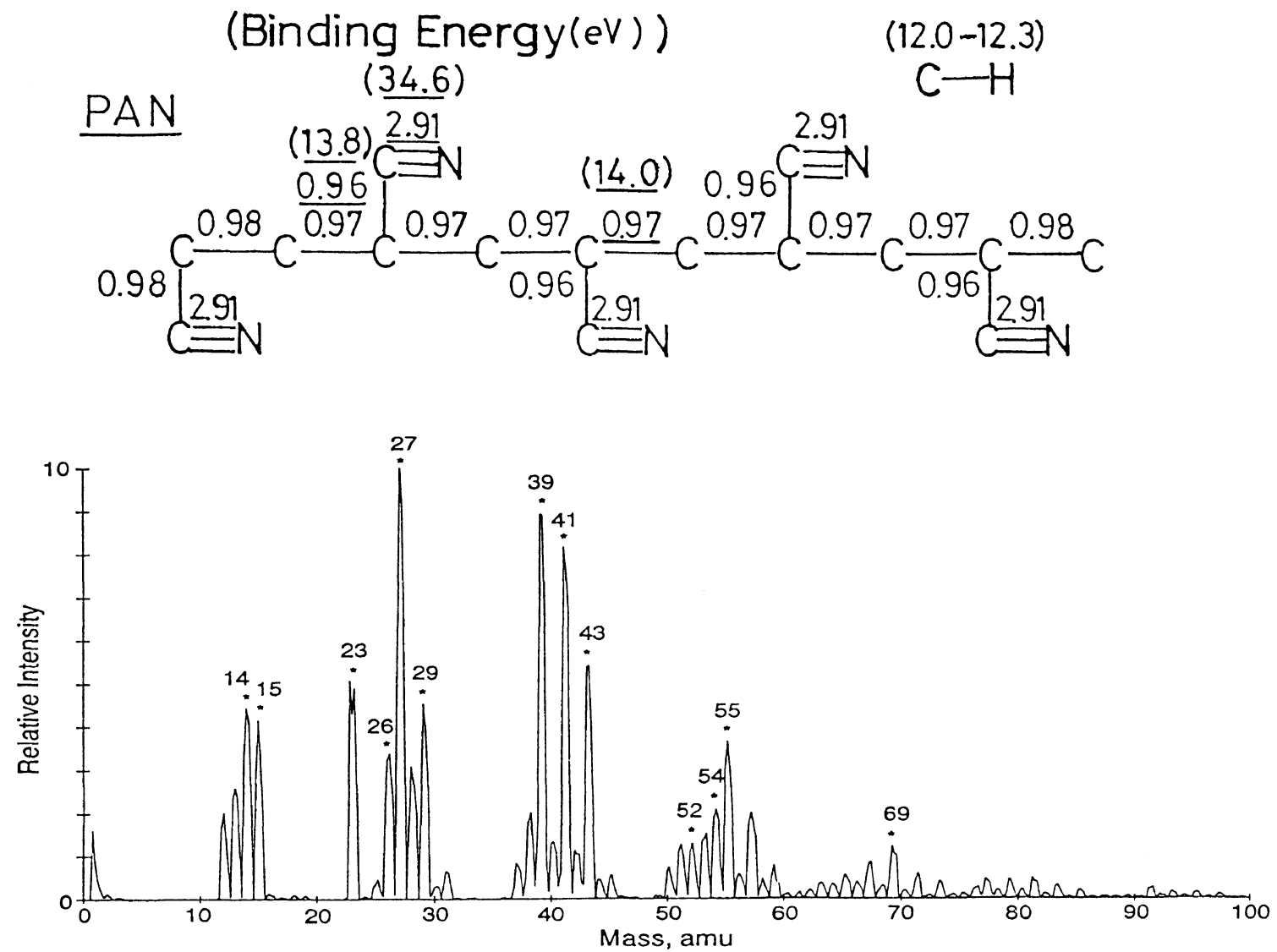

Figure 3. Bond-orders and bond energies (in eV) of the pentamer of PAN by semiempirical MO calculation using AM1 program (upper); positive-ion S-SIMS spectra of PAN in the range of $0-100 \mathrm{amu}$.

chain $\mathrm{C}-\mathrm{C}$ bonds are $14.0 \mathrm{eV}$ much less than $16.4 \mathrm{eV}$ of $\mathrm{C}-\mathrm{F}$ bonds. We can assume that the cleavage of the PTFE, PVA, and PVF polymers occurs at any bonds of main chain with side chain groups.

Cleavage thus occurs as: (a) at any bonds, as shown in PE, PVME, and PAN; (b) cleavage of the main chain occurs at any bonds, after side chain groups cleaved first, as indicated in PVC and PAM; (c) the cleavage of main chain carbon with the side chain group occurs at any bonds of main chain, as shown for PVF, PTFE, and PVA. Therefore, we analyzed the positive- and negative-ion fragment spectra of the polymers in TOFSIMS from the prediction of the cleavage for polymer-bond due to the two-center bond energy.

For PE (Figure 2a), there are many species of positive-ion fragment spectra in the mass range of 0 $100 \mathrm{amu}$. This seems to correspond to cleavage at any atom-atom bonds in case a). We observed six high intense positive-ion fragments, $\mathrm{C}_{2} \mathrm{H}_{3}{ }^{+}(27), \mathrm{C}_{2} \mathrm{H}_{5}{ }^{+}(29), \mathrm{C}_{3} \mathrm{H}_{3}{ }^{+}$ (39), $\mathrm{C}_{3} \mathrm{H}_{5}{ }^{+}$(41), $\mathrm{C}_{3} \mathrm{H}_{7}{ }^{+}$(43), and $\mathrm{C}_{4} \mathrm{H}_{7}{ }^{+}$. The negative-ion fragment consists of $\cdot \mathrm{C}^{-}(12)$, the most high intense line $\mathrm{CH}^{-}$(13), $\cdot \mathrm{CH}_{2}{ }^{-}(14), \mathrm{OH}^{-}(17)$, and $\mathrm{C}_{2} \mathrm{H}^{-}$ (25) which are considered stable.

In the case of PVME and PAN, many species of positive-ion fragment spectra were observed in the mass range of $0-100 \mathrm{amu}$ (Figures 2(b) and 3), since the cleavage of the polymer-bonds between carbon, oxygen, cyanogen and carbons occurs at any atom-atom bonds. The former involves $\mathrm{O}$-containing spectra of $\mathrm{CHO}^{+}(29)$ (For mass $29 \mathrm{amu}$, we obtained two fragments for the intense ratio of $2.4 / 1.1$ for $\mathrm{CHO}^{+} / \mathrm{C}_{2} \mathrm{H}_{5}{ }^{+}$.), $\mathrm{C}_{2} \mathrm{H}_{3} \mathrm{O}^{+}$
(43), $\mathrm{C}_{2} \mathrm{H}_{5} \mathrm{O}^{+}$(45), $\mathrm{C}_{3} \mathrm{H}_{7} \mathrm{O}^{+}$(59), $\mathrm{C}_{4} \mathrm{H}_{7} \mathrm{O}^{+}$(71), $\mathrm{C}_{3} \mathrm{H}_{7} \mathrm{O}_{2}{ }^{+}(75)$, and $\mathrm{C}_{5} \mathrm{H}_{9} \mathrm{O}^{+}$(85), while the latter does the $\mathrm{N}$-containing fragments of $\cdot \mathrm{N}^{+}(14), \cdot \mathrm{CN}^{+}(26)$, $\mathrm{C}_{3} \mathrm{H}_{2} \mathrm{~N}^{+}$(52), and $\mathrm{C}_{3} \mathrm{H}_{4} \mathrm{~N}^{+}$(54). For the negative-ion spectra of PVME, we obtained $\cdot \mathrm{C}^{-}(12), \mathrm{CH}^{-}(13), \cdot \mathrm{O}^{-}$ (16), $\mathrm{OH}^{-}(17)$, and $\mathrm{C}_{2} \mathrm{H}^{-}(25)$ as stable fragments.

For PVC in Figure 4(a), the positive-ion fragment spectra are very similar to those of hydrocarbon polymer (PE) in Figure 2(a). This implies that remainder polymer chains consist of carbon and hydrogen atoms, since the $\mathrm{Cl}$ atom changes stable $\mathrm{Cl}^{-} \mathrm{s}$ after the side chain atom $\mathrm{Cl}$ cleaved first. This is based on the finding that the two-center bond energies of 10.8 for $\mathrm{C}-\mathrm{Cl}$ are much less than 14.3 for main chain $\mathrm{C}-\mathrm{C}$ bonds of PVC. Thus, the negative-ion fragment spectra have intense isotope $\mathrm{Cl}^{-} \mathrm{s}$ (35 and 37) in Figure 4(a). In the case of PAM in Figure 4(b), we see a little different mass spectra from hydrocarbon polymers. The cleavage of the polymer-bonds may yield in a little complicated process, because the two-center bond energy of $\mathrm{C}-\mathrm{CO}\left(\mathrm{NH}_{2}\right), 13.1 \mathrm{eV}$, is slightly less than that of main chain $\mathrm{C}-\mathrm{C}$ bonds, $14.0 \mathrm{eV}$. Thus, the positive-ion fragments involving $\mathrm{N}$ and $\mathrm{O}$ atomes are $\mathrm{CH}_{2} \mathrm{~N}^{+}(28), \mathrm{C}_{2} \mathrm{H}_{3} \mathrm{O}^{+}(43), \mathrm{C}_{4} \mathrm{H}_{5} \mathrm{O}^{+}$(69), and $\mathrm{C}_{3} \mathrm{H}_{7} \mathrm{NO}^{+}$(73). In Figure 4(b), the stable negativeion spectra give $\cdot \mathrm{C}^{-}(12), \mathrm{CH}^{-}(13), \cdot \mathrm{O}^{-}(16), \mathrm{OH}^{-}$ (17), $\mathrm{C}_{2} \mathrm{H}^{-}(25)$, and $\cdot \mathrm{CN}^{-}$(26).

For PVA in Figure 5a in case c, the positive-ion fragment spectra are simple, since cleavage of the bonds between main chain carbons occurs first though the two-center bond energies of the main chain $\mathrm{C}-\mathrm{C}$ bonds were slightly less than the energies of $\mathrm{C}-\mathrm{O}$ bonds. We 
(a)
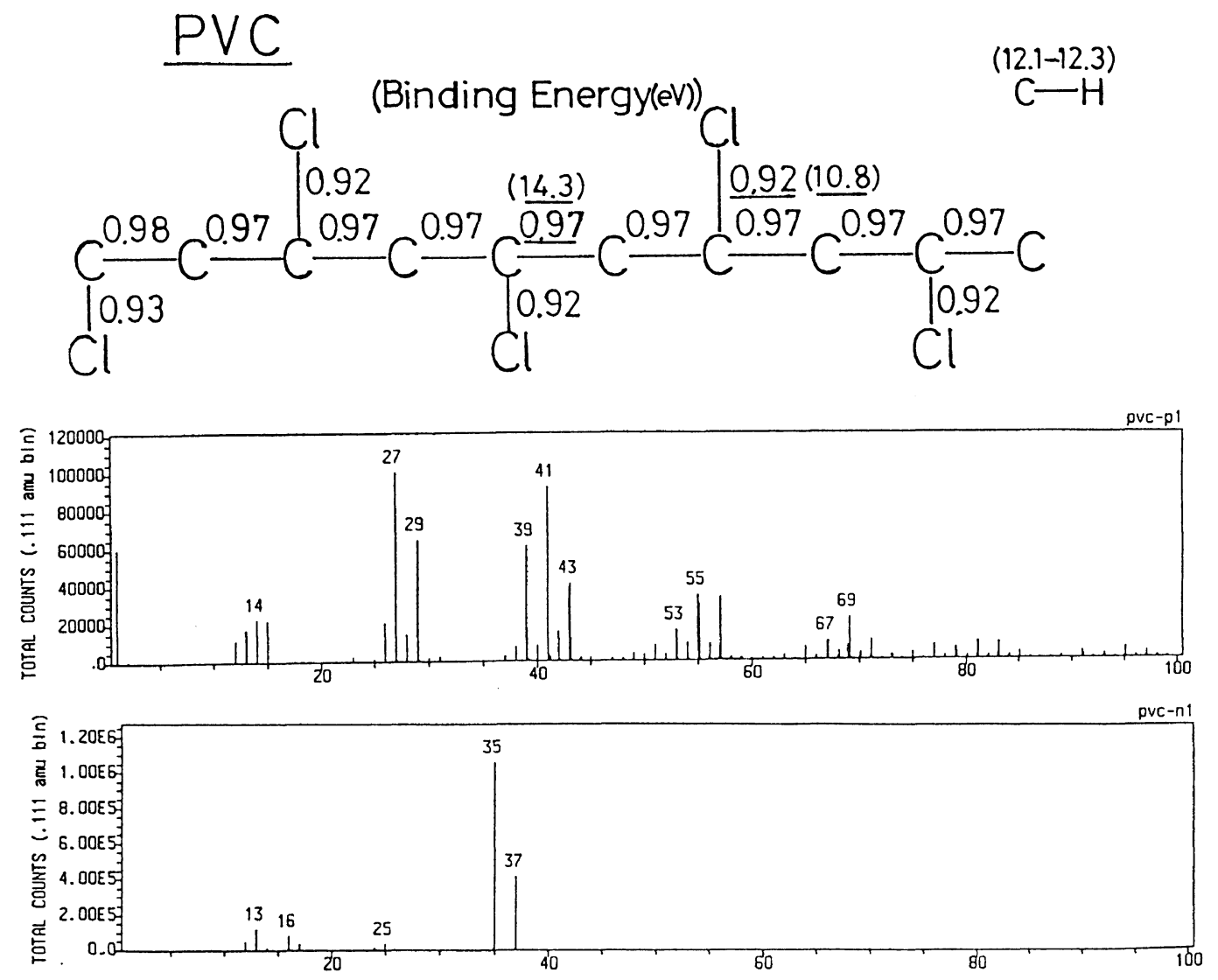

(b)
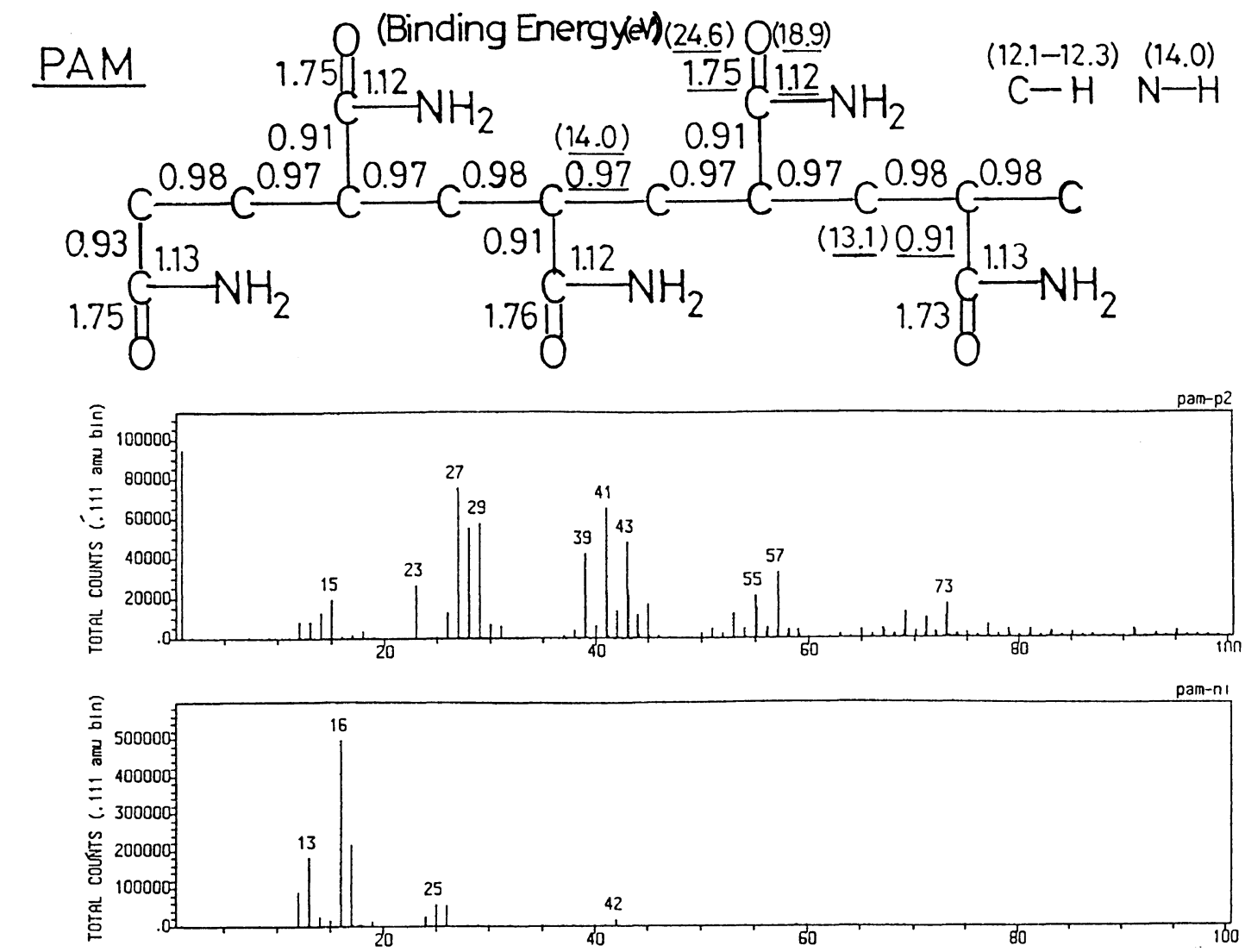

Figure 4. (a) Bond-orders and bond energies (in eV) of the pentamer of PVC by semiempirical MO calculation using AM1 program (upper); positive and negative ions TOF-SIMS spectra of PVC in the range of $0-100 \mathrm{amu}$. (b) Bond-orders and bond energies (in eV) of the pentamer of PAM by semiempirical MO calculation using AM 1 program (upper); positive and negative ions TOF-SIMS spectra of PAM in the range of 0 - 100 amu. 
(a)

$$
\text { PVA (Binding Energy(eV)) }
$$

$\mathrm{OH}$ 0.98
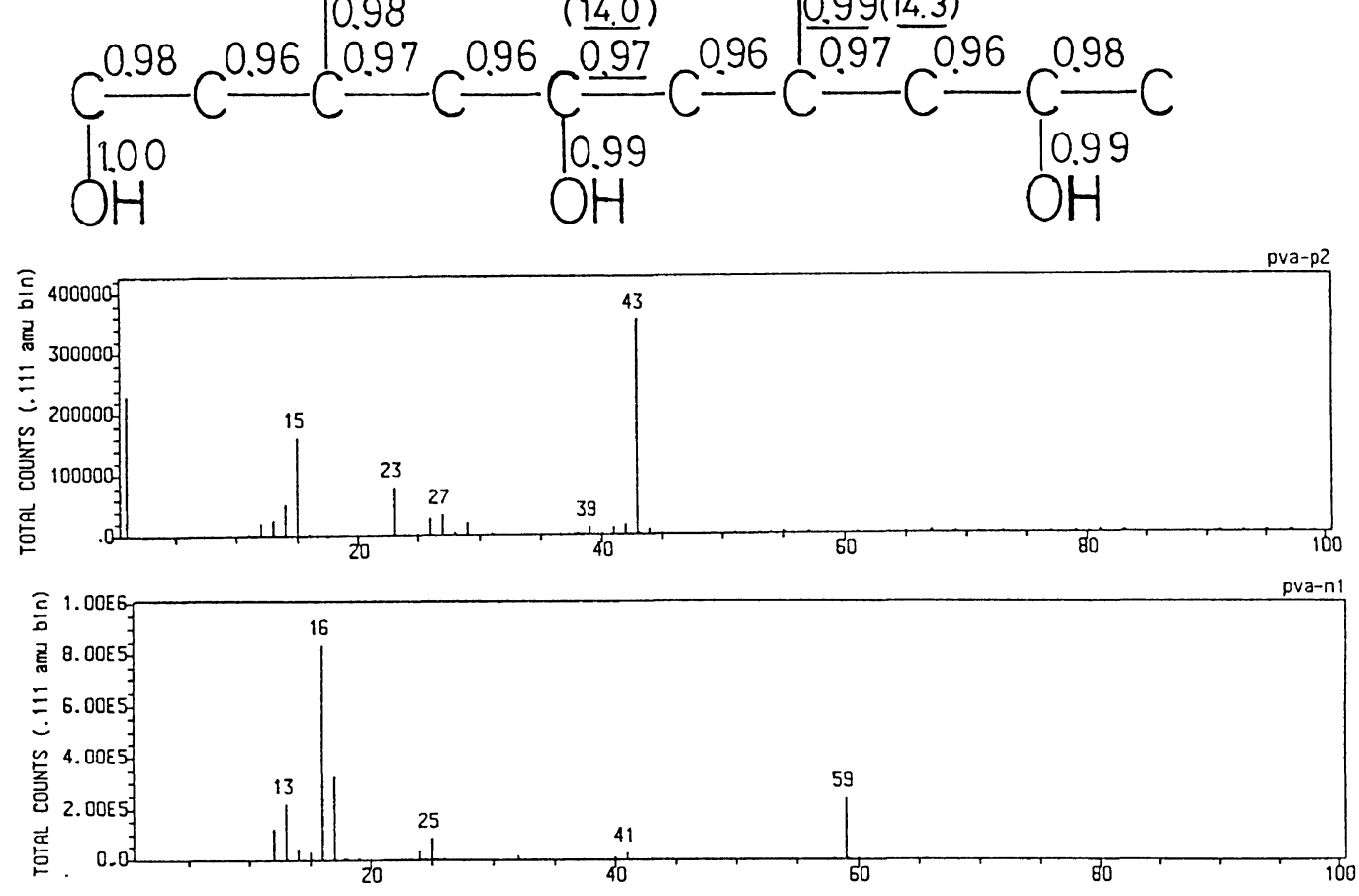

(b)
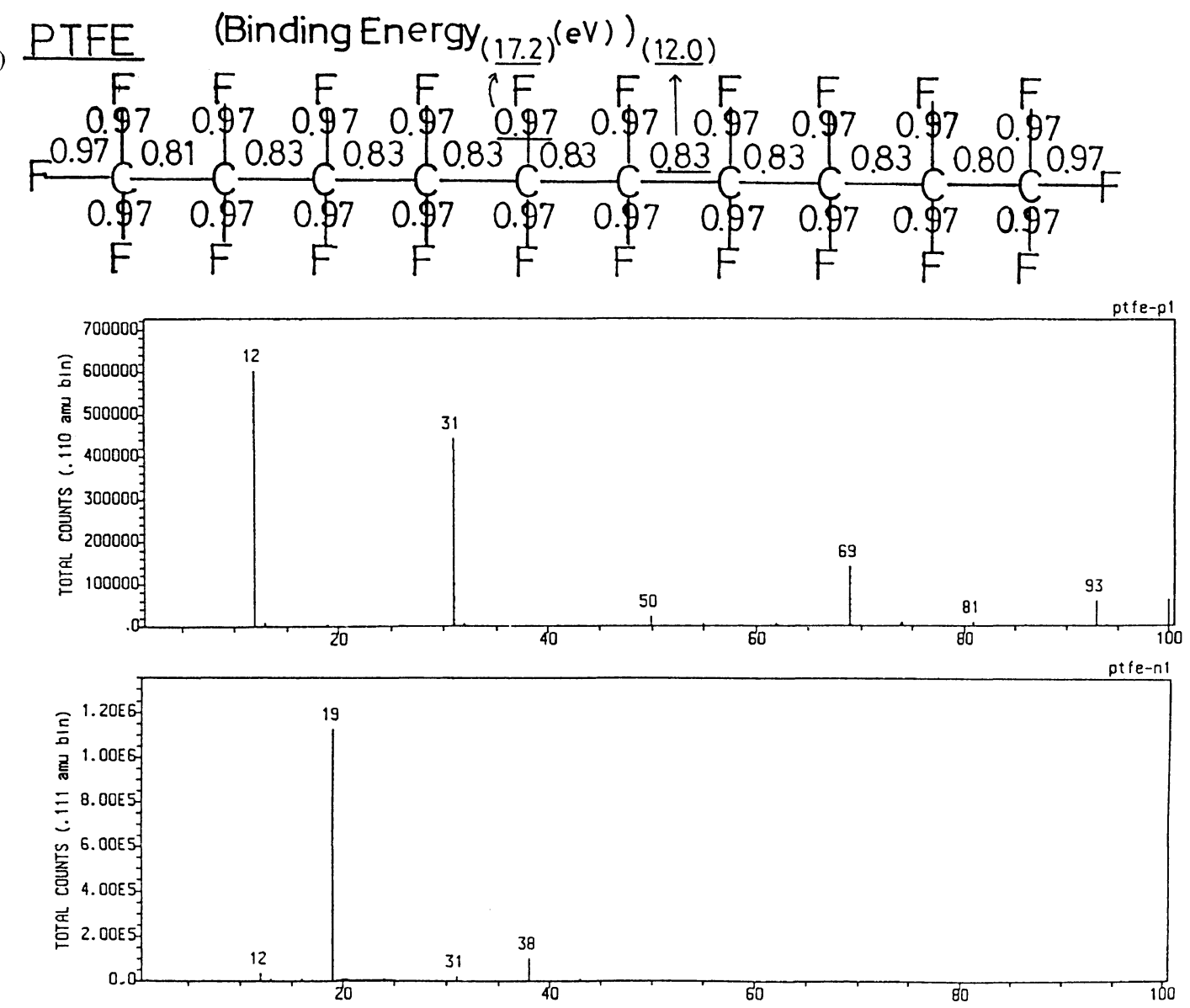

Figure 5. (a) Bond-orders and bond energies (in eV) of the pentamer of PVA by semiempirical MO calculation using AM1 program (upper); positive and negative ions TOF-SIMS spectra of PVA in the range of 0-100 amu. (b) Bond-orders and bond energies (in eV) of the pentamer of PTFE by semiempirical MO calculation using AMI program (upper); positive and negative ions TOF-SIMS spectra of PTFE in the range of $0-100 \mathrm{amu}$ 

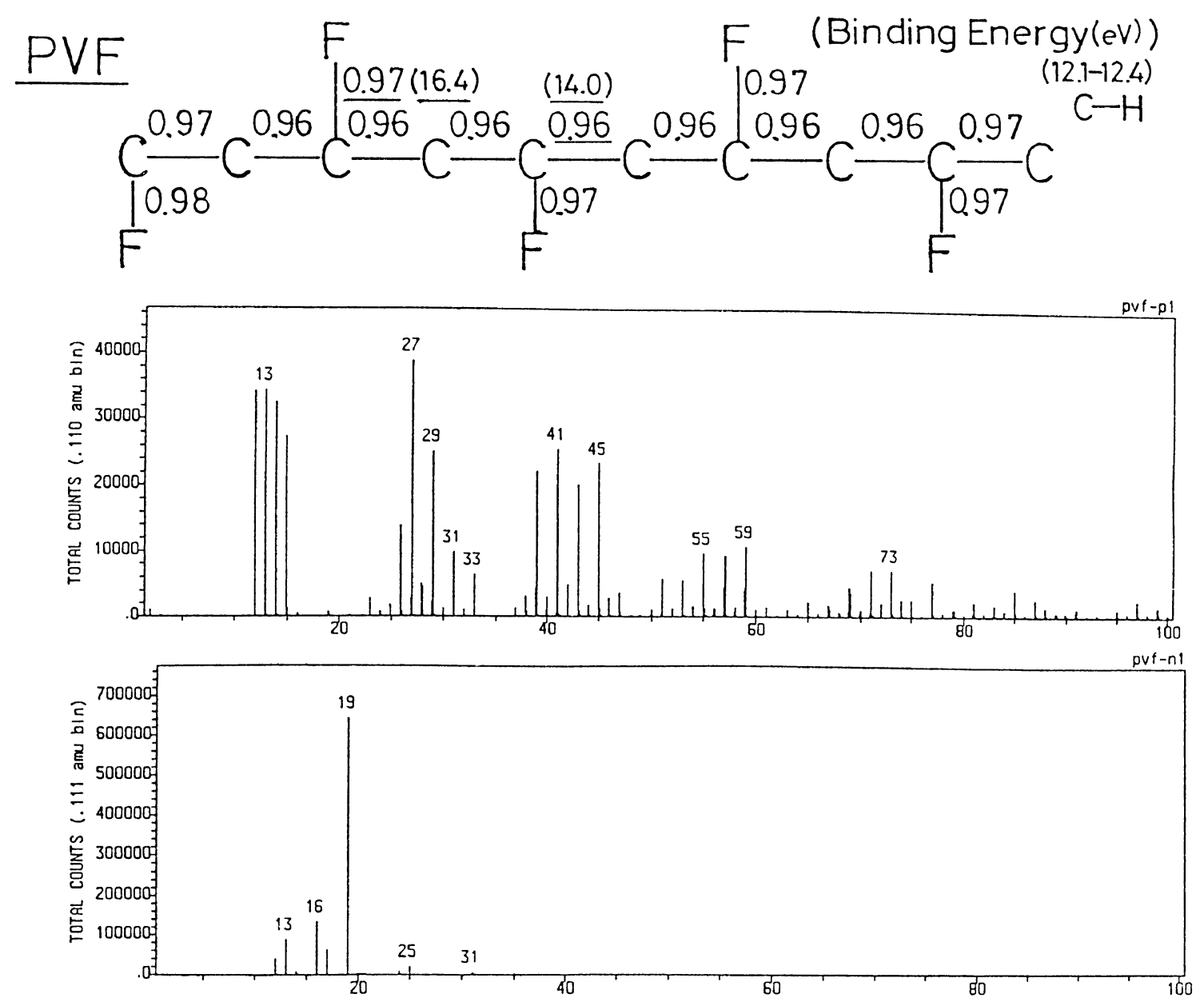

Figure 6. Bond-orders and bond energies (in eV) of the pentamer of PVF by semiempirical MO calculation using AM1 program (upper); positive and negative ions TOF-SIMS spectra of PVF in the range of $0-100 \mathrm{amu}$.

thus obtain the intensive spectrum $\mathrm{C}_{2} \mathrm{H}_{3} \mathrm{O}^{+}$(43) as $\mathrm{O}$-containing positive-ion fragment. In the case of the negative-ion fragments, there exist $\cdot \mathrm{C}^{-}(12), \mathrm{CH}^{-}(13)$, the intense spectrum $\cdot \mathrm{O}^{-}(16), \mathrm{OH}^{-}(17), \mathrm{C}_{2} \mathrm{H}^{-}(25)$, and $\mathrm{C}_{2} \mathrm{H}_{3} \mathrm{O}_{2}^{-}$(59) as $\mathrm{CH}_{3} \mathrm{COO}^{-}$.

For PTFE, we observed F-containig positive-ion fragments except for $\cdot \mathrm{C}^{+}(12)$, because the two-center bond energies of the main chain bonds of PTFE are much less than those of $\mathrm{C}-\mathrm{F}$ bonds, as indicated at the top of Figure 5(b). In the negative-ion mass spectra of Figure 5(b), we see the most stable characteristic mass spectrum and intense $\mathrm{F}^{-}$fragment.

In PVF in Figure 6, there are many positive-ion fragment lines, although two-center bond energies of the main chain $\mathrm{C}-\mathrm{C}$ bonds are much less than the values of $\mathrm{C}-\mathrm{F}$ bonds. The cleavage of PVF may occur in very complicated process with cleavage and recombination between positive-ion and neutral species. The F-containing positive-ion fragments are $\mathrm{CH}_{2} \mathrm{~F}^{+}(33), \mathrm{C}_{2} \mathrm{H}_{2} \mathrm{~F}^{+}$ (45), $\mathrm{C}_{3} \mathrm{H}_{4} \mathrm{~F}^{+}$(59), $\mathrm{C}_{4} \mathrm{H}_{4} \mathrm{~F}^{+}$(71), $\mathrm{C}_{4} \mathrm{H}_{6} \mathrm{~F}^{+}$(73), and $\mathrm{C}_{3} \mathrm{H}_{3} \mathrm{~F}_{2}{ }^{+}{ }^{(77)}$ in the middle site of Figure 6. The negative-ion fragment spectra at the lower site were obtained as $\cdot \mathrm{C}(12), \mathrm{CH}^{+}(13)$, the contaminants $\cdot \mathrm{O}^{-}$ (16) and $\mathrm{OH}^{-}$(17), the intensive line $\mathrm{F}^{-}(19)$ and $\mathrm{C}_{2} \mathrm{H}^{-}$ (25).

Polypropylene (PP) and polystyrene (PS) except phenyl rings in our previous work ${ }^{6}$ belong to case $\mathrm{a}$, while poly(methyl methacrylate) is considered cases $b$ and $a$; the pendant group $\left(-\mathrm{COOCH}_{3}\right)$ cleaved first, and then the remaining main-chains with side chain methyl groups cleave at any bonds as well as PP polymers.

\section{Structural Formulas of the Secondary Positive-Ion Frag- ments}

Chemical formulas of positive-ion fragments for eight polymers (in the left column of Tables I-III) were obtained from spectral mass analysis of TOF- and S-SIMS measurements. We here give reasonable structural formulas of positive-ion fragments of the polymers in SIMS by ab initio calculations using the HONDO7 program, although the formulas of positiveion fragments were empirically written by organic chemists. The tables show the possible structural formulas, dipole moments, heat of formation and total energies of the fragments for the eight polymers.

For example, in Table II, the most possible structural formula of $\mathrm{C}_{4} \mathrm{H}_{7}{ }^{+}$fragment is determined as $\mathrm{CH}_{3}-$ $\mathrm{CH}^{(1 / 2)+} \stackrel{-}{ } \mathrm{CH} \cdots \mathrm{CH}_{2}{ }^{(1 / 2)+}$ of the four formulas, since the heat of formation (or the total energy) is the least value from the $a b$ initio $\mathrm{MO}$ calculations. For another example in Table II, the most reasonable structural formula of $\mathrm{C}_{4} \mathrm{H}_{7} \mathrm{O}^{+}$fragment is $\mathrm{CH}_{3}-\mathrm{CH}_{2}-\mathrm{CH}_{2}-\mathrm{C}^{+}=$ $\mathrm{O}$ of the six formula. 
Table I. Structure, diople moment, heat of formation, and total energy of ion fragments in positive SIMS spectra of eight polymers (PE, PVA, PVF, PVC, PAN, PVME, PAM, PTFE)

\begin{tabular}{|c|c|c|c|c|c|}
\hline \multirow{3}{*}{ Composition (mass) } & \multicolumn{5}{|c|}{ Structure } \\
\hline & & $\mu$ (dipole moment) & & Heat of formation & $E$ (total energy) \\
\hline & & D (debye) & & $\mathrm{eV}$ & $\mathrm{eV}$ \\
\hline $\mathrm{C}^{+}(12)$ & $\cdot \mathrm{C}^{+}$ & {$[0.0000 \mathrm{D}$} & ; & $17.30 \mathrm{eV}$ & $-1017.661 \mathrm{eV}]$ \\
\hline $\mathrm{CH}^{+}(13)$ & $\mathrm{CH}^{+}$ & {$[2.113 \mathrm{D}$} & ; & $15.96 \mathrm{eV}$ & $-1029.684 \mathrm{eV}]$ \\
\hline$\cdot \mathrm{CH}_{2}^{+}(14)$ & $\cdot \mathrm{CH}_{2}{ }^{+}$ & {$[0.130 \mathrm{D}$} & ; & $13.35 \mathrm{eV}$ & $-1054.143 \mathrm{eV}]$ \\
\hline$\cdot \mathrm{N}^{+}(14)$ & $\cdot \mathrm{N}^{+}$ & {$[0.00000 \mathrm{D}$} & ; & $20.18 \mathrm{eV}$ & $-1460.967 \mathrm{eV}]$ \\
\hline $\mathrm{CH}_{3}{ }^{+}(15)$ & $\mathrm{CH}_{3}^{+}$ & {$[0.0004233 \mathrm{D}$} & ; & $10.94 \mathrm{eV}$ & $-1066.015 \mathrm{eV}]$ \\
\hline $\mathrm{Na}^{+}(23)$ & $\mathrm{Na}^{+}$ & {$[0.000 \mathrm{D}$} & ; & $5.48 \mathrm{eV}$ & $-4347.915 \mathrm{eV}]$ \\
\hline$\cdot \mathrm{C}_{2} \mathrm{H}_{2}{ }^{+}(26)$ & $\cdot \mathrm{CH}^{(1 / 2)+}=\mathrm{CH}^{(1 / 2)+}$ & {$[0.000474 \mathrm{D}$} & ; & $13.46 \mathrm{eV}$ & $-2092.895 \mathrm{eV}]$ \\
\hline$\cdot \mathrm{CN}^{+}(26)$ & $\cdot \mathrm{C}^{+}=\mathrm{N}$ & {$[1.941 \mathrm{D}$} & ; & $18.21 \mathrm{eV}$ & $-2406.406 \mathrm{eV}]$ \\
\hline $\mathrm{C}_{2} \mathrm{H}_{3}^{+}(27)$ & $\mathrm{CH}_{2}=\mathrm{CH}^{+}$ & {$[0.682 \mathrm{D}$} & ; & $11.34 \mathrm{eV}$ & $-2094.741 \mathrm{eV}]$ \\
\hline $\mathrm{CH}_{2} \mathrm{~N}^{+}(28)$ & $\mathrm{CH}^{+} \cong \mathrm{NH}$ & {$[0.686 \mathrm{D}$} & ; & $9.32 \mathrm{eV}$ & $-2531.231 \mathrm{eV}]$ \\
\hline $\mathrm{C}_{2} \mathrm{H}_{5}{ }^{+}(29)$ & $\mathrm{CH}_{3} \mathrm{CH}_{2}{ }^{+}$ & {$[1.800 \mathrm{D}$} & ; & $9.40 \mathrm{eV}$ & $-2127.904 \mathrm{eV}]$ \\
\hline $\mathrm{CHO}^{+}(29)$ & $\mathrm{CH}^{+} \cong \mathrm{O}$ & {$[4.645 \mathrm{D}$} & ; & $8.13 \mathrm{eV}$ & $-3068.906 \mathrm{eV}]$ \\
\hline $\mathrm{CF}^{+}(31)$ & $\mathrm{C}^{+} \mathrm{F}$ & {$[2.070 \mathrm{D}$} & ; & $10.72 \mathrm{eV}$ & $-3717.941 \mathrm{eV}]$ \\
\hline $\mathrm{CH}_{2} \mathrm{~F}^{+}(33)$ & $\mathrm{C}^{+} \mathrm{H}_{2} \mathrm{~F}$ & {$[4.734 \mathrm{D}$} & ; & $7.82 \mathrm{eV}$ & $-3752.358 \mathrm{eV}]$ \\
\hline $\mathrm{C}_{3} \mathrm{H}_{3}^{+}(39)$ & $\mathrm{CH}_{2} \cdots \mathrm{C} \cong \mathrm{CH}^{+}$ & {$[1.938 \mathrm{D}$} & ; & $11.85 \mathrm{eV}$ & $-3123.057 \mathrm{eV}]$ \\
\hline $\mathrm{C}_{3} \mathrm{H}_{5}^{+}(41)$ & $\begin{array}{c}\mathrm{CH}_{3}-\mathrm{CH}=\mathrm{CH}^{+} \\
\mathrm{CH}_{2}^{(1 / 2)+}-\mathrm{CH}=\mathrm{CH}_{2}^{(1 / 2)+} \\
\mathrm{CH}_{2}{ }^{+}-\mathrm{CH}=\mathrm{CH}_{2}\end{array}$ & $\begin{array}{l}{[2.382 \mathrm{D}} \\
{[1.028 \mathrm{D}} \\
{[2.944 \mathrm{D}}\end{array}$ & ; & $\begin{array}{r}10.90 \mathrm{eV} \\
9.81 \mathrm{eV} \\
10.13 \mathrm{eV}\end{array}$ & $\begin{array}{l}-3155.916 \mathrm{eV}] \\
-3157.295 \mathrm{eV}] \\
-3155.451 \mathrm{eV}]\end{array}$ \\
\hline $\mathrm{C}_{3} \mathrm{H}_{7}^{+}(43)$ & $\mathrm{CH}_{3}-\mathrm{CH}_{2}-\mathrm{CH}_{2}^{+}$ & {$[3.995 \mathrm{D}$} & ; & $9.18 \mathrm{eV}$ & $-3188.693 \mathrm{eV}]$ \\
\hline $\mathrm{C}_{2} \mathrm{H}_{3} \mathrm{O}^{+}(43)$ & 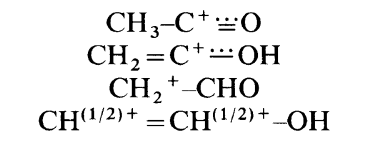 & $\begin{array}{l}{[3.619 \mathrm{D}} \\
{[2.406 \mathrm{D}} \\
{[7.456 \mathrm{D}} \\
{[3.641 \mathrm{D}}\end{array}$ & $\begin{array}{l}; \\
; \\
;\end{array}$ & $\begin{array}{l}7.14 \mathrm{eV} \\
8.54 \mathrm{eV} \\
9.60 \mathrm{eV} \\
9.90 \mathrm{eV}\end{array}$ & $\begin{array}{l}-4131.210 \mathrm{eV}] \\
-4129.639 \mathrm{eV}] \\
-4128.083 \mathrm{eV}] \\
-4128.208 \mathrm{eV}]\end{array}$ \\
\hline $\mathrm{C}_{2} \mathrm{H}_{5} \mathrm{O}^{+}(45)$ & $\begin{array}{l}\mathrm{CH}_{3}-\mathrm{CH}^{+} \cong \mathrm{OH} \\
\mathrm{CH}_{2}+-\mathrm{CH}_{2}-\mathrm{OH} \\
\mathrm{CH}_{3}-\mathrm{O}-\mathrm{CH}_{2}{ }^{+}\end{array}$ & $\begin{array}{l}{[2.868 \mathrm{D}} \\
{[4.694 \mathrm{D}} \\
{[2.842 \mathrm{D}}\end{array}$ & ; & $\begin{array}{l}6.16 \mathrm{eV} \\
7.62 \mathrm{eV} \\
6.86 \mathrm{eV}\end{array}$ & $\begin{array}{l}-4163.249 \mathrm{eV}] \\
-4155.104 \mathrm{eV}] \\
-4162.574 \mathrm{eV}]\end{array}$ \\
\hline $\mathrm{C}_{2} \mathrm{H}_{2} \mathrm{~F}^{+}(45)$ & $\mathrm{CF}^{+}=\mathrm{CH}_{2}$ & {$[4.098 \mathrm{D}$} & ; & $9.27 \mathrm{eV}$ & $-4780.288 \mathrm{eV}]$ \\
\hline$\cdot \mathrm{CF}_{2}{ }^{+}(50)$ & $\cdot \mathrm{CF}_{2}{ }^{+}$ & {$[0.682 \mathrm{D}$} & ; & $7.77 \mathrm{eV}$ & $-6457.844 \mathrm{eV}]$ \\
\hline
\end{tabular}

Table II. Structure, diople moment, heat of formation, and total energy of ion fragments in positive SIMS spectra of eight polymers (PE, PVA, PVF, PVC, PAN, PVME, PAM, PTFE)

\begin{tabular}{|c|c|c|c|c|c|}
\hline \multirow{3}{*}{ Composition (mass) } & \multicolumn{5}{|c|}{ Structure } \\
\hline & & $\mu$ (dipole moment) & & Heat of formation & $E$ (total energy) \\
\hline & & D (debye) & & $\mathrm{eV}$ & $\mathrm{eV}$ \\
\hline $\mathrm{CHF}_{2}{ }^{+}(51)$ & $\mathrm{C}^{+} \mathrm{HF}_{2}$ & {$[3.733 \mathrm{D}$} & ; & $5.28 \mathrm{eV}$ & $-6438.682 \mathrm{eV}]$ \\
\hline $\mathrm{C}_{3} \mathrm{H}_{2} \mathrm{~N}^{+}$ & $\mathrm{CH}_{2}=\mathrm{C}^{+}-\mathrm{C} \cong \mathrm{N}$ & {$[6.182 \mathrm{D}$} & ; & $12.76 \mathrm{eV}$ & $-4586.492 \mathrm{eV}]$ \\
\hline $\mathrm{C}_{4} \mathrm{H}_{5}{ }^{+}(53)$ & $\mathrm{CH}_{2}=\mathrm{CH}-\mathrm{CH}=\mathrm{CH}_{2}^{+}$ & {$[3.600 \mathrm{D}$} & ; & $11.88 \mathrm{eV}$ & $-4199.651 \mathrm{eV}]$ \\
\hline
\end{tabular}


Table II. (Continued)

\begin{tabular}{|c|c|c|c|c|c|}
\hline \multirow[b]{2}{*}{ Composition (mass) } & \multicolumn{5}{|c|}{ Structure } \\
\hline & & $\mu$ (dipole moment) & & Heat of formation & $E$ (total energy) \\
\hline $\mathrm{C}_{3} \mathrm{H}_{4} \mathrm{~N}^{+}(54)$ & $\mathrm{CH}_{3}-\mathrm{CH}^{+}-\mathrm{C} \equiv \mathrm{N}$ & {$[5.384 \mathrm{D}$} & ; & $11.00 \mathrm{eV}$ & $-4619.612 \mathrm{eV}]$ \\
\hline $\mathrm{C}_{4} \mathrm{H}_{7}{ }^{+}(55)$ & $\begin{array}{c}\mathrm{CH}_{3}-\mathrm{CH}_{2}-\mathrm{CH}=\mathrm{CH}^{+} \\
\mathrm{CH}_{3}-\mathrm{CH}^{(1 / 2)+}-\mathrm{CH}-\mathrm{CH}_{2}^{(1 / 2)+} \\
\mathrm{CH}_{2}=\mathrm{CH}-\mathrm{CH}_{2}-\mathrm{CH}_{2}^{+} \\
\mathrm{CH}_{2}^{(1 / 2)+}-\mathrm{C}\left(\mathrm{CH}_{3}\right)-\mathrm{CH}_{2}^{(1 / 2)+}\end{array}$ & $\begin{array}{l}{[4.213 \mathrm{D}} \\
{[1.639 \mathrm{D}} \\
{[5.845 \mathrm{D}} \\
{[2.714 \mathrm{D}}\end{array}$ & $\begin{array}{l}; \\
;\end{array}$ & $\begin{array}{r}10.56 \mathrm{eV} \\
8.93 \mathrm{eV} \\
10.03 \mathrm{eV} \\
9.42 \mathrm{eV}\end{array}$ & $\begin{array}{l}-4216.662 \mathrm{eV}] \\
-4218.628 \mathrm{eV}] \\
-4216.944 \mathrm{eV}] \\
-4218.119 \mathrm{eV}]\end{array}$ \\
\hline $\mathrm{C}_{4} \mathrm{H}_{9}{ }^{+}(57)$ & $\begin{array}{c}\mathrm{CH}_{3}-\mathrm{CH}_{2}-\mathrm{CH}_{2}-\mathrm{CH}_{2}^{+} \\
\mathrm{CH}_{3}-\mathrm{CH}^{+}-\mathrm{CH}_{2}-\mathrm{CH}_{3}\end{array}$ & $\begin{array}{l}{[4.547 \mathrm{D}} \\
{[2.555 \mathrm{D}}\end{array}$ & ; & $\begin{array}{l}8.81 \mathrm{eV} \\
8.01 \mathrm{eV}\end{array}$ & $\begin{array}{l}-4149.566 \mathrm{eV}] \\
-4250.256 \mathrm{eV}]\end{array}$ \\
\hline $\mathrm{C}_{3} \mathrm{H}_{2} \mathrm{~F}^{+}(57)$ & $\mathrm{CH}_{2}=\mathrm{C}=\mathrm{C}^{+} \mathrm{F}$ & {$[6.264 \mathrm{D}$} & ; & $10.09 \mathrm{eV}$ & $-5809.131 \mathrm{eV}]$ \\
\hline $\mathrm{C}_{3} \mathrm{H}_{7} \mathrm{O}^{+}$ & $\begin{array}{c}\mathrm{CH}_{3}-\mathrm{CH}_{2}-\mathrm{C}^{+} \mathrm{H}-\mathrm{OH} \\
\mathrm{CH}_{3}-\mathrm{CH}_{2}-\mathrm{O}-\mathrm{C}^{+} \mathrm{H}_{2} \\
\mathrm{CH}_{3}-\mathrm{CH}^{+}-\mathrm{O}-\mathrm{CH}_{3} \\
\mathrm{CH}_{3}-\mathrm{C}^{+}\left(\mathrm{CH}_{3}\right) \mathrm{OH} \\
\mathrm{CH}_{3}-\mathrm{CH}\left(\mathrm{CH}_{2}^{+}\right)-\mathrm{OH}\end{array}$ & $\begin{array}{l}{[3.563 \mathrm{D}} \\
{[4.485 \mathrm{D}} \\
{[2.617 \mathrm{D}} \\
{[2.033 \mathrm{D}} \\
{[4.097 \mathrm{D}}\end{array}$ & $\begin{array}{l}; \\
; \\
; \\
;\end{array}$ & $\begin{array}{l}5.80 \mathrm{eV} \\
6.45 \mathrm{eV} \\
6.08 \mathrm{eV} \\
5.47 \mathrm{eV} \\
7.37 \mathrm{eV}\end{array}$ & $\begin{array}{l}-5223.906 \mathrm{eV}] \\
-5223.479 \mathrm{eV}] \\
-5223.996 \mathrm{eV}] \\
-5224.583 \mathrm{eV}] \\
-5222.310 \mathrm{eV}]\end{array}$ \\
\hline $\mathrm{C}_{3} \mathrm{H}_{4} \mathrm{~F}^{+}(59)$ & $\mathrm{C}^{+} \mathrm{HF}-\mathrm{CH} \cdots \mathrm{CH}_{2}$ & {$[5.276 \mathrm{D}$} & ; & $7.44 \mathrm{eV}$ & $-5843.614 \mathrm{eV}]$ \\
\hline $\mathrm{C}_{5} \mathrm{H}_{7}^{+}(67)$ & $\begin{array}{c}\mathrm{CH}_{3}-\mathrm{CH}=\mathrm{CH}-\mathrm{CH}=\mathrm{CH}^{+} \\
\mathrm{CH}_{2}=\mathrm{CH}-\mathrm{CH}_{2}-\mathrm{CH}=\mathrm{CH}^{+} \\
\mathrm{CH}_{2}^{(1 / 2)+}-\mathrm{CH}-\mathrm{CH}-\mathrm{CH}-\mathrm{CH}_{2}^{(1 / 2)+}\end{array}$ & $\begin{array}{l}{[5.419 \mathrm{D}} \\
{[6.427 \mathrm{D}} \\
{[1.316 \mathrm{D}}\end{array}$ & ; & $\begin{array}{r}8.97 \mathrm{eV} \\
11.58 \mathrm{eV} \\
9.65 \mathrm{eV}\end{array}$ & $\begin{array}{l}-5245.315 \mathrm{eV}] \\
-5244.908 \mathrm{eV}] \\
-5247.502 \mathrm{eV}]\end{array}$ \\
\hline $\mathrm{C}_{5} \mathrm{H}_{9}{ }^{+}(69)$ & $\begin{array}{c}\mathrm{CH}_{3}-\mathrm{C}^{(1 / 2)+}\left(\mathrm{CH}_{3}\right) \cdots \mathrm{CH} \cdots \mathrm{CH}_{2}^{(1 / 2)+} \\
\mathrm{CH}_{3}-\mathrm{CH}_{2}-\mathrm{CH}^{(1 / 2)+}-\mathrm{CH}-\mathrm{CH}_{2}^{(1 / 2)+} \\
\mathrm{CH}_{2}=\mathrm{CH}-\mathrm{CH}_{2}-\mathrm{CH}_{2}-\mathrm{CH}_{2}{ }^{+}\end{array}$ & $\begin{array}{l}{[1.094 \mathrm{D}} \\
{[2.571 \mathrm{D}} \\
{[7.082 \mathrm{D}}\end{array}$ & $\begin{array}{l}; \\
;\end{array}$ & $\begin{array}{l}8.33 \mathrm{eV} \\
8.69 \mathrm{eV} \\
9.73 \mathrm{eV}\end{array}$ & $\begin{array}{l}-5279.698 \mathrm{eV}] \\
-5279.217 \mathrm{eV}] \\
-5277.673 \mathrm{eV}]\end{array}$ \\
\hline $\mathrm{C}_{4} \mathrm{H}_{5} \mathrm{O}^{+}(69)$ & $\begin{array}{c}\mathrm{CH}_{3}-\mathrm{C}\left(\mathrm{CH}_{2}\right)-\mathrm{C}^{+} \cong \mathrm{O} \\
\mathrm{CH}_{3}-\mathrm{CH}=\mathrm{CH}-\mathrm{C}^{+} \cong \mathrm{O}\end{array}$ & $\begin{array}{l}{[2.877 \mathrm{D}} \\
{[2.282 \mathrm{D}}\end{array}$ & ; & $\begin{array}{l}7.70 \mathrm{eV} \\
7.36 \mathrm{eV}\end{array}$ & $\begin{array}{l}-6220.682 \mathrm{eV}] \\
-6220.985 \mathrm{eV}]\end{array}$ \\
\hline $\mathrm{CF}_{3}{ }^{+}(69)$ & $\mathrm{C}^{+} \mathrm{F}_{3}$ & {$[0.00315 \mathrm{D}$} & ; & $3.56 \mathrm{eV}$ & $-9125.565 \mathrm{eV}]$ \\
\hline
\end{tabular}

Table III. Structure, diople moment, heat of formation, and total energy of ion fragments in positive SIMS spectra of eight polymers (PE, PVA, PVF, PVC, PAN, PVME, PAM, PTFE)

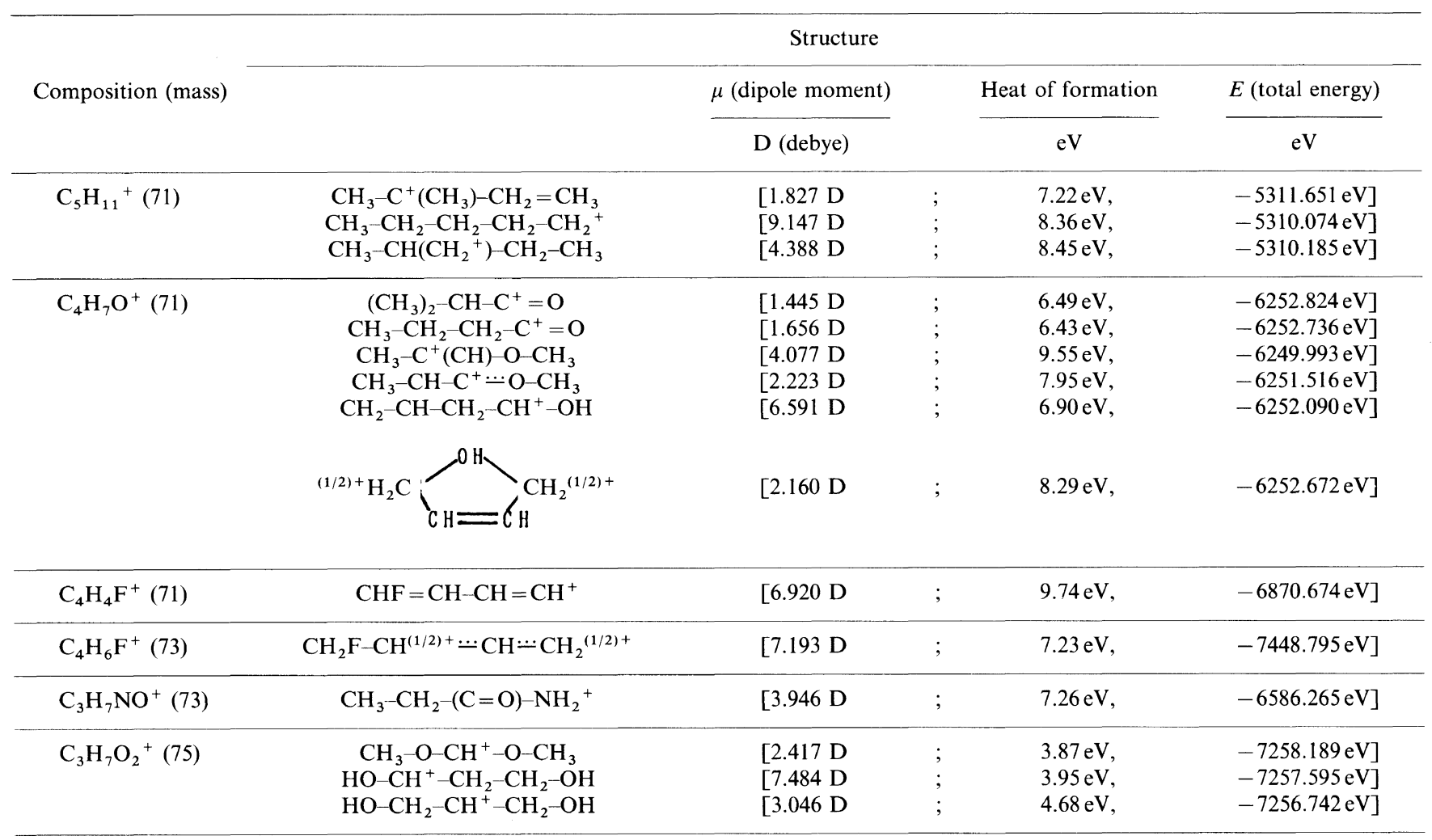


Table III. (Continued)

\begin{tabular}{|c|c|c|c|c|c|}
\hline \multirow{3}{*}{ Composition (mass) } & \multicolumn{5}{|c|}{ Structure } \\
\hline & & $\mu$ (dipole moment) & & Heat of formation & $E$ (total energy) \\
\hline & & D (debye) & & $\mathrm{eV}$ & $\mathrm{eV}$ \\
\hline $\mathrm{C}_{3} \mathrm{H}_{3} \mathrm{~F}_{2}{ }^{+}$ & $\begin{array}{c}\mathrm{CH}_{2} \cdots \mathrm{CF}-\mathrm{C}^{+} \mathrm{HF} \\
\mathrm{C}^{(1 / 2)+} \mathrm{HF}=\mathrm{CH}=\mathrm{C}^{(1 / 2)+} \mathrm{HF}\end{array}$ & $\begin{array}{l}{[7.423 \mathrm{D}} \\
{[3.654 \mathrm{D}}\end{array}$ & ; & $\begin{array}{l}6.02 \mathrm{eV} \\
5.21 \mathrm{eV}\end{array}$ & $\begin{array}{l}-8529.315 \mathrm{eV}] \\
-8529.821 \mathrm{eV}]\end{array}$ \\
\hline $\mathrm{C}_{5} \mathrm{H}_{9} \mathrm{O}^{+}(85)$ & $\begin{array}{c}\mathrm{CH}_{3}-\mathrm{C}^{+}\left(\mathrm{OCH}_{3}\right)-\mathrm{CH}=\mathrm{CH}_{2} \\
\mathrm{CH}_{3}-\mathrm{O}-\mathrm{CH}_{2}-\mathrm{CH}_{2}-\mathrm{CH}=\mathrm{CH}^{+} \\
\mathrm{CH}_{2}=\mathrm{CH}-\mathrm{CH}^{+}\left(\mathrm{CH}_{2}\right)-\mathrm{O}-\mathrm{CH}_{3} \\
\mathrm{CH}_{2}=\mathrm{CH}-\mathrm{CH}_{2}-\mathrm{CH}_{2}-\mathrm{O}-\mathrm{CH}_{2}^{+} \\
\mathrm{CH}_{3}-\mathrm{CH}_{2}-\mathrm{CH}_{2}-\mathrm{CH}_{2}-\mathrm{C}^{+}=\mathrm{O}\end{array}$ & $\begin{array}{l}{[2.257 \mathrm{D}} \\
{[9.910 \mathrm{D}} \\
{[4.653 \mathrm{D}} \\
{[8.699 \mathrm{D}} \\
{[3.727 \mathrm{D}}\end{array}$ & $\begin{array}{l}; \\
; \\
; \\
;\end{array}$ & $\begin{array}{l}6.41 \mathrm{eV} \\
8.83 \mathrm{eV} \\
8.58 \mathrm{eV} \\
7.24 \mathrm{eV} \\
6.12 \mathrm{eV}\end{array}$ & $\begin{array}{l}-7313.822 \mathrm{eV}] \\
-7311.348 \mathrm{eV}] \\
-7311.416 \mathrm{eV}] \\
-7312.267 \mathrm{eV}] \\
-7313.402 \mathrm{eV}]\end{array}$ \\
\hline $\mathrm{C}_{5} \mathrm{H}_{6} \mathrm{~F}^{+}(85)$ & $\mathrm{CH}_{3}-\mathrm{CH}=\mathrm{CH}-\mathrm{CH}=\mathrm{C}^{+} \mathrm{F}$ & {$[1.907 \mathrm{D}$} & ; & $9.14 \mathrm{eV}$ & $-7930.751 \mathrm{eV}]$ \\
\hline $\mathrm{C}_{3} \mathrm{~F}_{3}+(93)$ & $\mathrm{C}^{+} \mathrm{F}_{2}-\mathrm{C}=\mathrm{CF}$ & {$[0.940 \mathrm{D}$} & ; & $9.81 \mathrm{eV}$ & $-11181.387 \mathrm{eV}]$ \\
\hline$\cdot \mathrm{C}_{2} \mathrm{~F}_{4}{ }^{+}(100)$ & $\cdot \mathrm{C}^{(1 / 2)+} \mathrm{F}_{2}-\mathrm{C}^{(1 / 2)+} \mathrm{F}_{2}$ & {$[0.00623 \mathrm{D}$} & ; & $2.18 \mathrm{eV}$ & $-12931.402 \mathrm{eV}]$ \\
\hline
\end{tabular}

\section{CONCLUSIONS}

We analyzed the spectra of eight polymers in SIMS by MO calculation using model pentamers.

(1) The prediction for cleavage of polymer-bonds on sputtering can be determined by the bond-orders (two-center bond energies) of the pentamers by a semiempirical MO calculation; a) cleavage occurs at any bonds (PE, PVME, PAN), b) cleavage of the main chain occurs at any bonds, after side chain groups cleaved first (PVC, PAM), c)the main chain carbons with the side chain group cleave at any bonds of the main chain (PVF, PTFE, PVA).

(2) We gave reasonable structural formulas, dipole moments, heat of formation and total energies of each positive-ion fragment of the polymers in SIMS by $a b$ initio calculations using the HONDO7 program.

\section{REFERENCES}

1. P. A. Zimmerman and D. M. Hercules, Anal. Chem., 65, 983 (1993).
2. D. Briggs, in "Practical Surface Analysis," Vol. 2, Ion and Neutral Spectroscopy, by D. Briggs and M. P. Seah, Ed., Wiley, Chichester, 1992, p 367.

3. I. V. Bletsos, D. M. Hercules, D. VanLeyen, A. Benningho ven, C. G. Karakatsanis, and J. N. Rieck, Macromolecules, 23, 4157 (1990).

4. I. V. Bletsos, D. M. Hercules, D. VanLeyen, A. Benningho ven, C. G. Karakatsanis, and J. N. Rieck, Anal. Chem., 61, 2142 (1989).

5. A. Benninghoven, F. G. Rudenauer, and H. W. Werner, in "Secondary Ion Mass Spectrometry," P. J. Elving and J. D. Winefordner, Ed., Wiely, Chichester, 1987.

6. K. Endo, N. Kobayashi, M. Aida, and T. Hoshi, Polym. J., 28, 901 (1996).

7. M. J. S. Dewar and E. G. Zoebisch, Theochem, 180, 1 (1988); M. J. S. Dewar, E. G. Zoebisch, E. F. Healy, and J. J. P. Stewart, J. Am. Chem. Soc., 107, 3902 (1985).

8. M. S. Dupuis, J. D. Watts, H. G. Villar, and G. J. B. Hurst, HONDO, version 7; Scientific and Engineering Computations Dept. 48B, IBM Corp; New York, N.Y., 1240; 1978.

9. T. Hirano, Kagakusosetsu, 5, 19 (1989); T. Hirano and E. Osawa, Croatica Chem. Acta, 57, 1633 (1984).

10. J. G. Newman, B. A. Carlson, R. S. Michael, J. F. Moulder, and T. A. Hohlt, "Static SIMS Handbook of Polymer Analysis," Perkin-Elmer Corp., Physical Electronics Division; Elden Prairie, Minnesota, 1991. 